\title{
Mineralogy and Geochemistry of A Low Grade Iron Ore Sample from Bellary-Hospet Sector, India and Their Implications on Beneficiation
}

\author{
D. S. Rao*, T. V. Vijaya Kumar, S. Subba Rao, S. Prabhakar and G. Bhaskar Raju
}

\author{
National Metallurgical Laboratory - Madras Centre, \\ CSIR Madras Complex, Taramani, Chennai - 600113 \\ Email:nmldsr@yahoo.co.in \\ *Present address: Mineralogy Department, \\ Institute of Minerals and Materials Technology, \\ Bhubaneswar - 751 013, Orissa, India
}

\begin{abstract}
The gradual depletion of high-grade iron ores has necessitated the exploitation of low/off grade iron ore reserves of India. The role of geochemical and mineralogical characterization is paramount to arrive at the process flow sheet development for such complex ores. Detailed studies were conducted on iron ores of Bellary-Hospet sector using microscope, XRD, TG, and EPMA techniques. The results indicate that hematite is the major iron oxide mineral with minor amounts of goethite, magnetite, martite and limonite with quartz and clay as major gangue. There is no evidence of the presence of any iron silicate and iron carbonate minerals. Trace amounts of pyrite were observed under the microscope and is the only iron sulphide phase. Microscopic studies also indicated that most of the quartz grains are present as inclusions within the hematite and magnetite grains. XRD studies revealed hematite as the major mineral with subordinate amounts of goethite, quartz and kaolinite confirming to the microscopic findings. Qualitative mapping and quantitative EPMA studies on these ores indicated the presence of gibbsite as the only alumina bearing phase and apatite as phosphorous bearing mineral. Traces of alumina, present as solid solution in the iron oxide minerals, has also contributed $\mathrm{Al}_{2} \mathrm{O}_{3}$ to the ores. Electron microscopic studies revealed that gibbsite grains are in the size range of 10 to 50 microns and are intimately and intricately associated with the iron oxide phases. Major elemental analyses of 47 representative iron ore samples of various types were analyzed to deduce the source of silica and alumina's contributing phases in the ore and their interrelationships. The geochemistry data revealed negative correlation of $\mathrm{Fe}_{2} \mathrm{O}_{3}$ with silica and alumina thus indicating there is no iron silicate phase as well as alumina contribution from iron
\end{abstract}


oxide minerals in the form of solid solution is insignificant. Positive correlation of silica with alumina indicates that the clay is the major contributing mineral for both the silica and alumina phase and presence of gibbsite. The role of gangue minerals and the interrelationship of silica, alumina and iron oxide, with reference to beneficiation are discussed. Jigs and heavy media cyclones for this type of ores can be used but at the cost of poor yield because of complex nature of alumina distribution. As long as alumina and silica mineralization is not too fine and the ore composed of magnetite/hematite with coarse grained quartz, magnetic route is the most effective. Since the quartz grains are too fine and their distribution is very complex for the Bellary-Hospet sector ores, flotation in general and column flotation in particular seems to be more effective.

Key words: Iron ores, Mineralogy, EPMA, Geochemistry, Flotation

\section{INTRODUCTION}

Although India is having vast reserves of iron ore, lack of consistency with respect to $\mathrm{Al}_{2} \mathrm{O}_{3} / \mathrm{SiO}_{2}$ ratio makes these ores unsuitable to use directly in the metallurgical industries without prior beneficiation. It has also been established that the adverse effects of high alumina to silica ratio (ideally it should be $<1$ ) is detrimental to blast furnace as well as sinter plant productivity. Indian iron ores are being beneficiated by washing, scrubbing, hydrocycloning, gravity separation and magnetic separation. During sizing and washing operations the enrichment with respect to iron content is marginal and gangue reduction with particular reference to favorable $\mathrm{Al}_{2} \mathrm{O}_{3} / \mathrm{SiO}_{2}$ is minimized. For better blast furnace productivity and slag flowability it is desirable to have the alumina silica ratio at 1:1 in the blast furnace feed.

The quality specifications attached to the iron ores by steel makers is contrary to what nature has provided. In other words, there exists a wide gap between the need and the reality. On an average, 1.6 tonne of iron ore is required either as lumps or sinters to produce one tonne of hot metal. The present day specifications of iron ore are

Physical Close sized lumps mostly $(-40 \mathrm{~mm}+10 \mathrm{~mm})$

\{However, fines $(-10 \mathrm{~mm})$ are also used after sintering\}.

Chemical High in Fe (65\% Fe) content and low in alumina (preferably less than 2.5\%)

Higher the iron content in the ore higher is the blast furnace productivity (as per the operating practices, the increase of Fe concentration in the feed by $1 \%$ will increase the productivity by 1.5 to $2.5 \%$ and reduce the coke consumption by $0.8 \%$ to $1.2 \%$ ). The reduction of alumina in blast 
furnace feed, reduces the rate of coke consumption, slag flowability and increases the digestion of the metal in the blast furnace.

Mineralogical Mostly hematite (easy reducibility, narrow/low softening and melting range as compared to magnetite)

Of course, the most important iron ore property to be used as feed in the blast furnace is the consistency in all the above three qualities i.e. regularity of its physical, chemical as well as mineralogical properties. Any variations in feed leads to unstable furnace operations as well as inconsistent finished quality metal. In other words, the performance of steel plants in respect of productivity, quality and cost depends largely on the above (physical, chemical and mineralogical) characteristics. None of the Indian iron ore deposits can produce iron ores having alumina below $2 \%$ preferred by blast furnaces. The reality is somewhat different. In some deposits it may be possible to achieve alumina below $2 \%$ in lumps but fines usually analyze alumina from 2.5 to $4.5 \%$ after crushing and washing. To overcome this disadvantage of Indian iron ores, efforts have been directed to reduce alumina in iron ore lumps as well as fines so as to bring down the levels of alumina in sinter to at least around $2.5 \%$ which is still higher than the International standards of less than $2 \%$ alumina. However, lowering of alumina to the desired levels by iron makers will lead to

$>\quad$ Increase in cost by adopting suitable beneficiation practices

$>\quad$ Incidence of fines and super fines in the final stages

$>\quad$ Cost of sintering and pelletisation

In total, the Indian iron ores, in general, contain adverse alumina content and require beneficiation to reduce the same in the ore for feeding to the blast furnace. Simple techniques like crushing, scrubbing and washing of iron ores are being adopted to reduce alumina but these techniques have their own inherent limitations and they are not effective to reduce alumina below particular limits. This process limitation along with the demand by the steel plants for low alumina iron ores encouraged researchers to characterize the ores in general and different modes of associations of alumina in particular. In view of this, an attempt has been made to understand the different modes of association of silica and alumina in iron ore sample form Bellary-Hospet sector, Karnataka in the present paper.

\section{MINERALOGICAL CHARACTERISATION}

\subsection{Macroscopic Study}

Considerable information can be drawn by macroscopic (unaided eye, with hand lens and/or with the stereomicroscopy) study. For example, whether crystalline or amorphous nature of the ore; soft or hard, or flaky ore or blue dust ore material, can be evaluated. Hard ore (generally contains high iron and less alumina), as the name indicates, is hard and compact ore of steel grey in 
colour. Flaky ore (lean in iron content and rich in alumina) which is laminated type with alternate bands of iron ore as well as gangue and is friable. Flaky ore and blue dust (generally contains high iron and less alumina) are inherently soft and contain very high percentage of natural fines. Soft ore (worst as compared to other types since they contain high alumina and low iron) shows varying characteristics and is lumpy in nature. These physical characteristics had great impact on the grinding and further processing as they contain varying amounts of silica and alumina, which is considered to be harmful in the blast furnace.

Hence, the present iron ore sample from Bellary-Hospet sector was studied megascopically. Study of the hand picked iron ore samples indicated that the ores can be grouped into three ore types.

1. Hard ore: Hard ore as the name indicates is a hard and compact ore of steel grey colour.

2. Flakey ore: Flakey ore which is of laminated type occur as flakes. Flakey ore is inherently soft and powdery in nature and contains very high percentage of fines.

3. Wad (soft ore): This is soft, light grey in colour, earthy, low specific gravity and noncrystalline ore. Typically it contains mixtures of oxy-hydroxides of iron and silicate gangue material and is the worst of the three types and contains high alumina, silica and low iron.

In the hard ore hand specimens banding are observed both megascopically and microscopically while in medium hard ores the laminations are vague due to intense leaching and presence of innumerable voids (Figs.1-3). The hard ores usually show massive texture. Kaolinite occurs as irregular patches and thin films. In rare instances wad is also observed along with the sample (Fig.4).

\subsection{Microscopic Study}

Polish section study revealed that the as received iron ore sample contain hematite and goethite as the major mineral with minor accessories of martite, maghemite while quartz and kaolinite occurs as gangue minerals. Maghemite appears as skeletal patches. Rarely specular hematite is also noticed in the hard ores. Many times minute crystals of silicate grains present as inclusions with in the hematite and magnetite. Quartz appears as minute grain of different sizes (Figs.5 and 6). Such inclusions pose problem for liberation. 

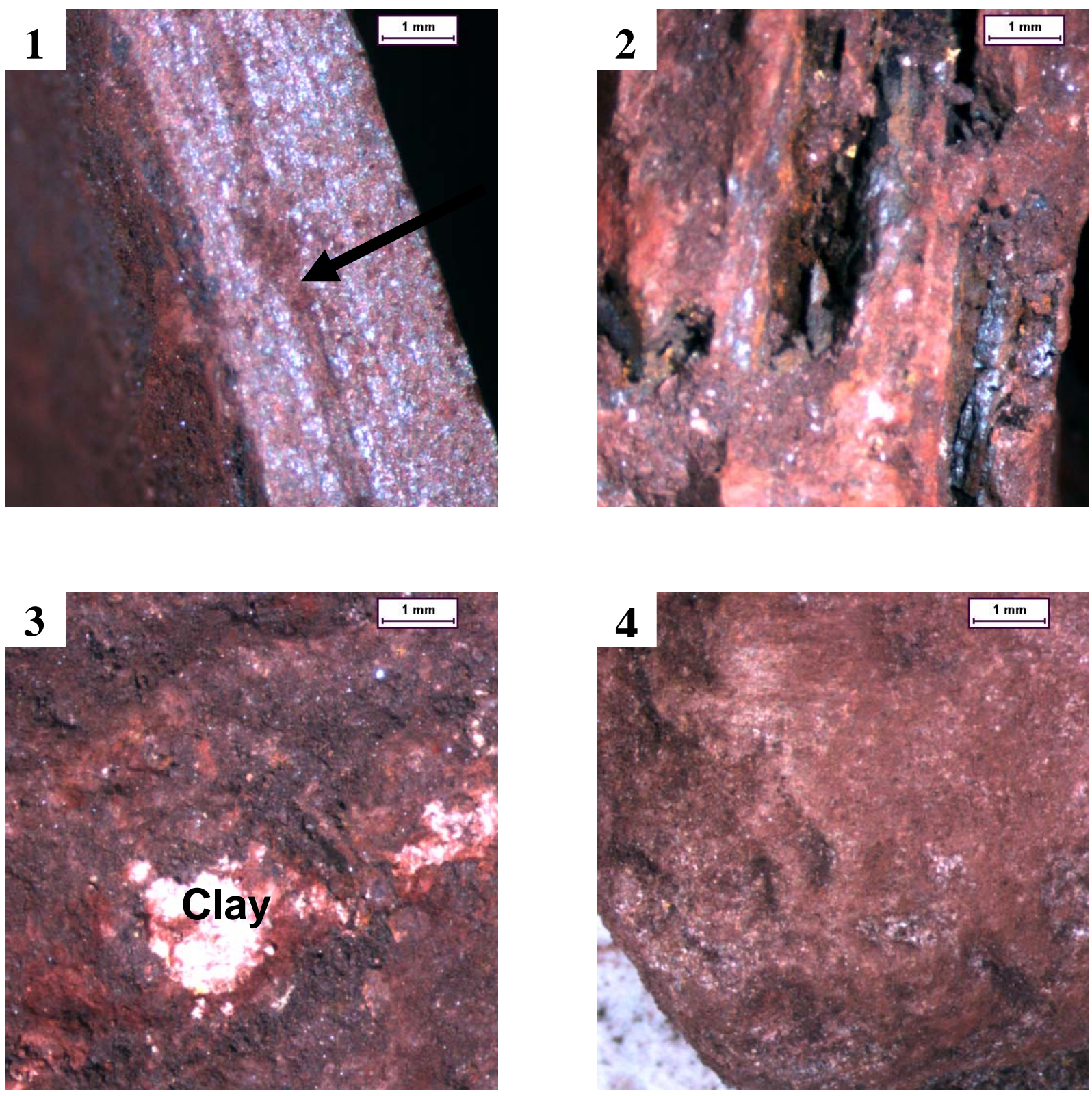

Fig.1: Hematite occurs in the platy/banded structure showing bands of Silicates shown by arrow). Stereomicroscopic photomicrograph.

Fig.2: Hematite shows banding of iron oxide minerals with silicates and porous structure. Stereomicroscopic photomicrograph.

Fig.3: Patches of clay (white) and silicates are present within iron ore pieces.

Stereomicroscopic photomicrograph.

Fig.4: Rarely pieces of wad were present in the lumpy hand specimens. Stereomicroscopic photomicrograph. 


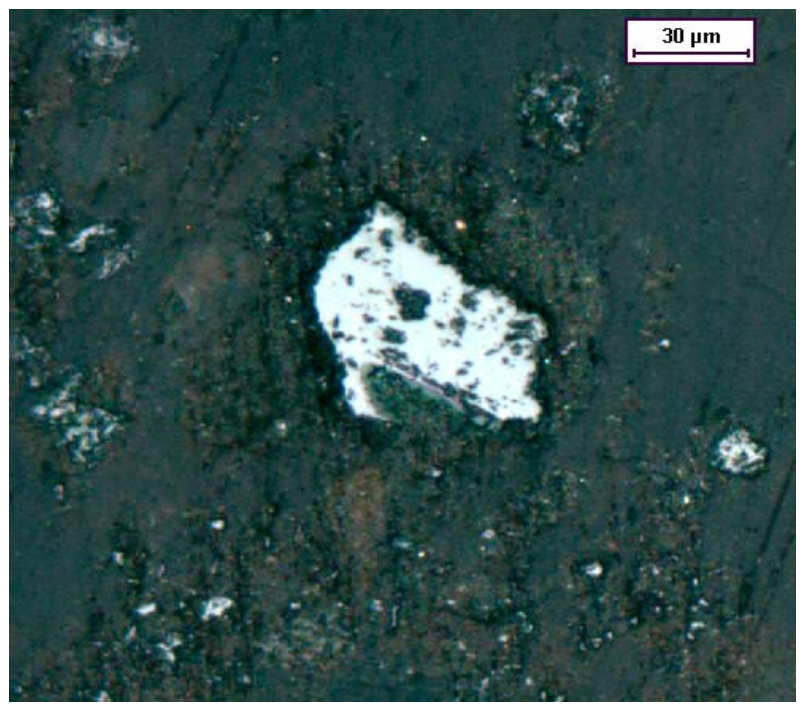

Fig. 5: Magnetite (white at the centre) is also observed in the head sample. It can be observed that there are numerous tiny inclusions of silicate gangue minerals within magnetite. Reflected light Microscopic photomicrograph.
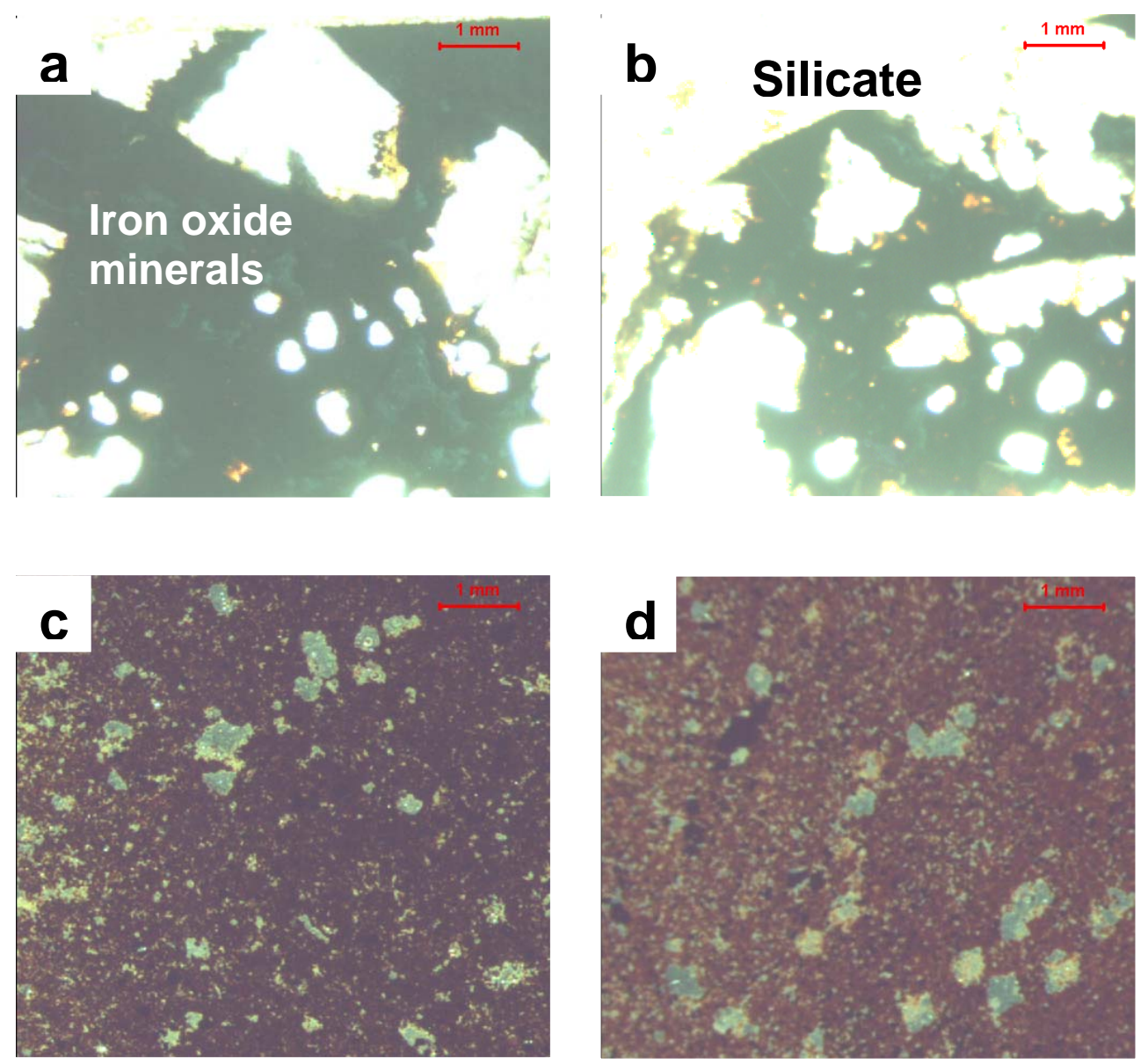

Fig.6: (a to d) Minute inclusions of silicate gangue (white grains in and b) present within the iron ore minerals (black) in different shapes and sizes. Transmitted light Microscopy. 


\subsection{XRD Studies}

XRD analysis of the as received head sample revealed (Fig.7 and Table 1) that the major iron bearing opaque minerals are hematite (JCPDS No.33-664) followed by goethite (JCPDS No.29713). The other silicate gangue minerals identified are quartz $\left(\mathrm{SiO}_{2}, \mathrm{JCPDS}\right.$ No.33-1161) and kaolinite $\left\{\mathrm{Al}_{2} \mathrm{Si}_{2} \mathrm{O}_{5}(\mathrm{OH})_{4}\right.$, JCPDS No.14-0164\}.

\section{Head sample XRD analysis}

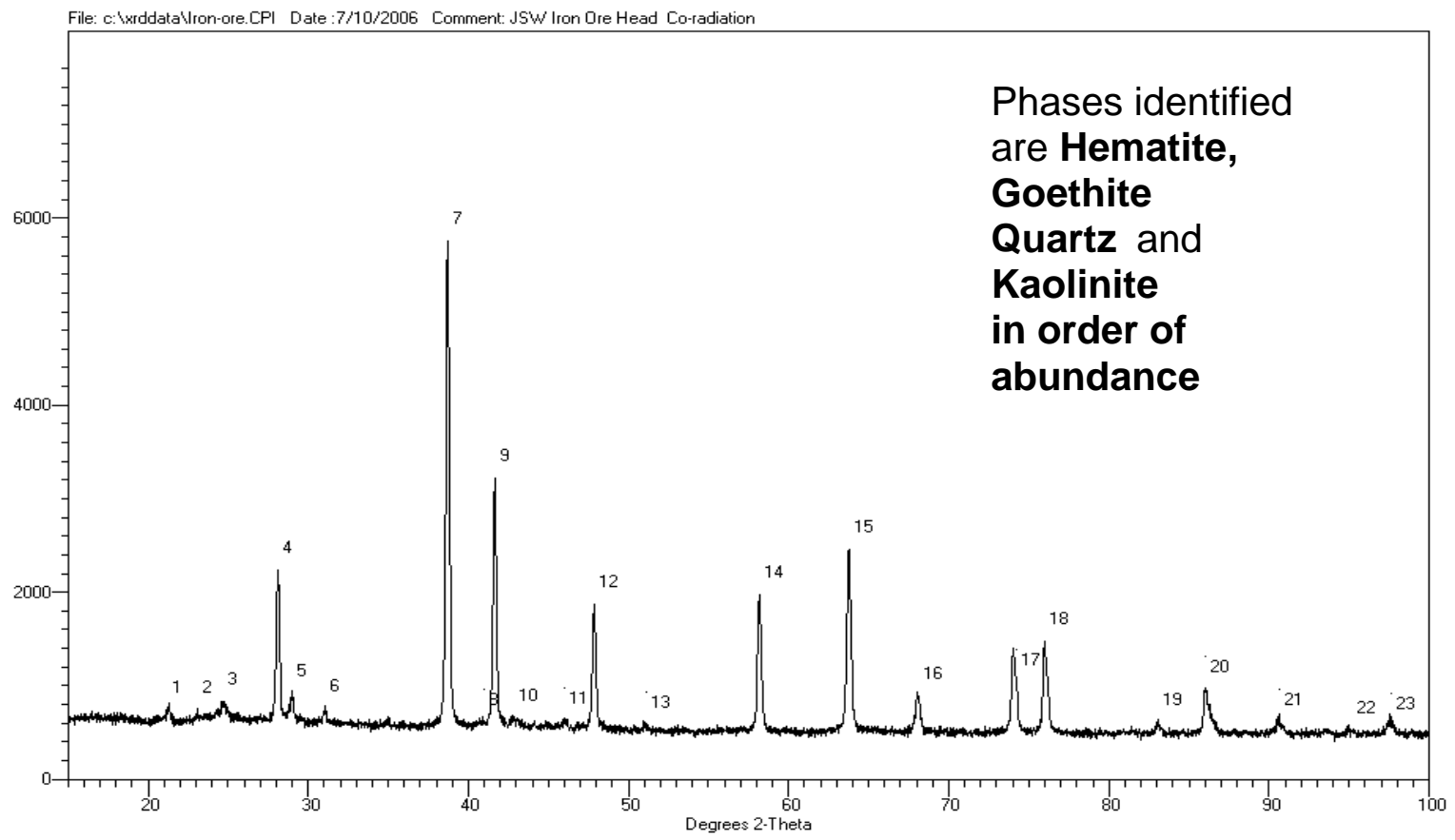

Fig. 7: XRD pattern of the as received powder sample 
Table 1: Phase identification of the XRD peaks

\begin{tabular}{llllll} 
No & Angle & Counts & D space & Rel I & \multicolumn{1}{c}{ Phases identified } \\
1 & 21.18 & 742 & 4.867 & 13 & Goethite \\
2 & 23.12 & 749 & 4.464 & 13 & Kaolinite \\
3 & 24.70 & 830 & 4.182 & 14 & Goethite / Kaolinite \\
4 & 28.12 & 224 & 3.682 & 39 & Hematite \\
5 & 28.96 & 921 & 3.577 & 16 & Goethite / Kaolinite \\
6 & 31.10 & 758 & 3.337 & 13 & Goethite/Quartz/Kaolinite \\
7 & 38.72 & 575 & 2.698 & 100 & Hematite / Goethite \\
8 & 40.96 & 621 & 2.557 & 11 & Goethite / Kaolinite \\
9 & 41.64 & 322 & 2.516 & 56 & Hematite / Goethite \\
10 & 42.84 & 661 & 2.449 & 11 & Goethite/Quartz/Kaolinite \\
11 & 46.00 & 633 & 2.289 & 11 & Hematite/Goethite/Quartz/Kaolinite \\
12 & 47.88 & 187 & 2.204 & 33 & Hematite / Goethite / Kaolinite \\
13 & 51.14 & 591 & 2.072 & 10 & Hematite / Goethite / Kaolinite \\
14 & 58.20 & 197 & 1.839 & 34 & Hematite/Goethite/Quartz/Kaolinite \\
15 & 63.78 & 245 & 1.693 & 43 & Hematite/Goethite/Quartz/Kaolinite \\
16 & 68.10 & 889 & 1.598 & 15 & Hematite/Goethite/Quartz/Kaolinite \\
17 & 74.22 & 104 & 1.483 & 18 & Hematite / Goethite / \\
18 & 75.96 & 147 & 1.454 & 26 & Hematite / Goethite / Quartz \\
19 & 83.08 & 610 & 1.349 & 11 & Hematite \\
20 & 86.06 & 971 & 1.311 & 17 & Hematite \\
21 & 90.68 & 620 & 1.258 & 11 & Hematite / Quartz \\
22 & 95.16 & 527 & 1.212 & 9 & Hematite / Quartz \\
23 & 97.66 & 576 & 1.188 & 10 & Hematite / Quartz
\end{tabular}




\subsection{TG Analysis}

The weight loss below $200^{\circ} \mathrm{C}$ of the TG plot (Fig.8) indicates loss of surfacial water or the adsorbed water of the sample. The dehydration (loss of structural water) of goethite takes place around $400^{\circ} \mathrm{C}$ while that of kaolinite takes place between $400^{\circ} \mathrm{C}$ to $850^{\circ} \mathrm{C}$ and that for hematite is beyond $850^{\circ} \mathrm{C}$. The TG analysis and the weight loss observed correlates well with that of the chemical analysis results.

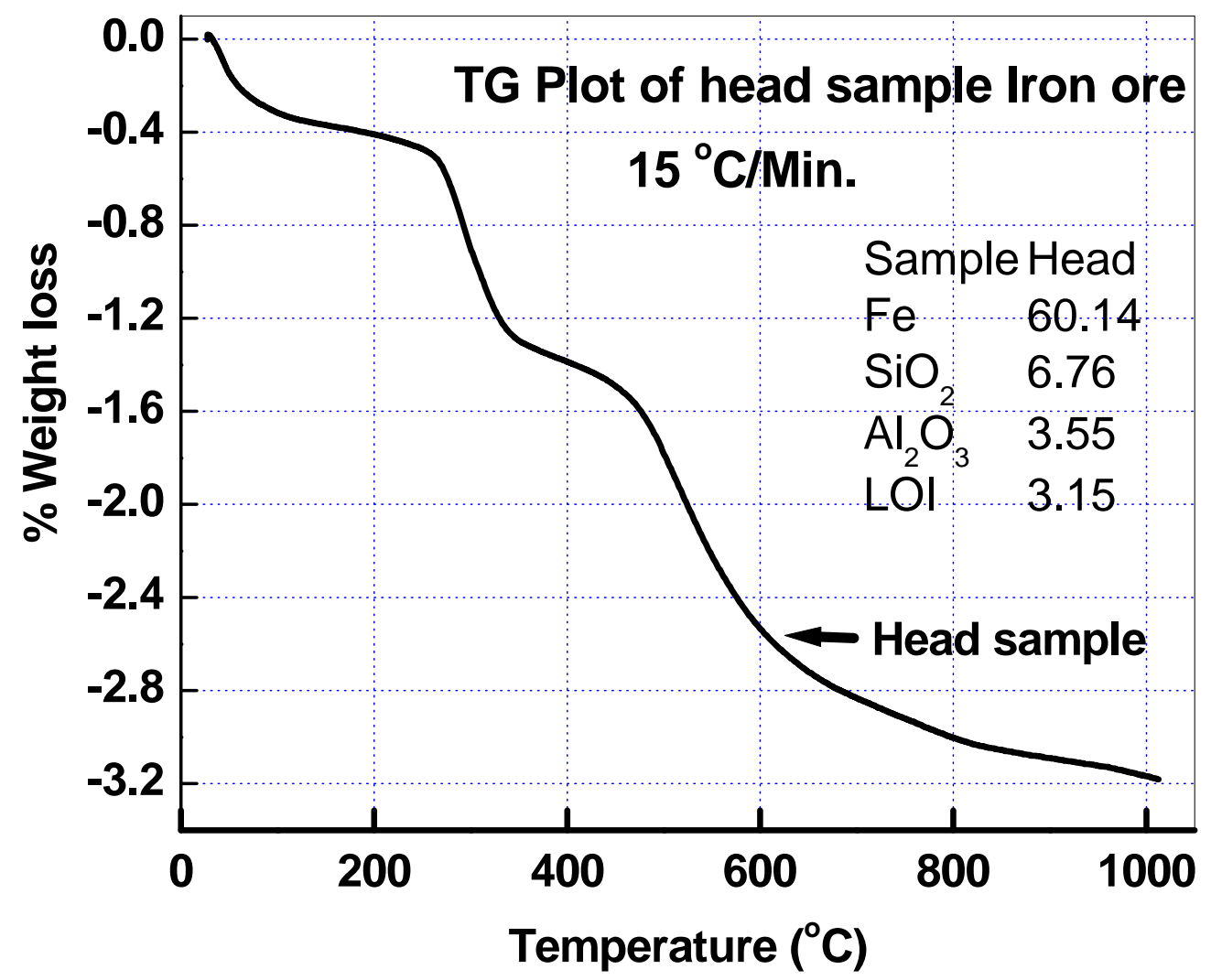

Fig.8: TG plots of the as received sample

\subsection{EPMA Studies}

A few samples were studied under the electron microscope to decipher the gibbsite. It was observed that minute inclusions of gibbsite (Fig.9), in the range of 10 to 50 microns, occur within the iron oxide minerals. They are very intricately and intimately present along with the iron ore minerals the liberation of which is very difficult. Quantitative EPMA analysis of iron ore minerals along with their associated phases indicated that alumina is present in more or less all the phases but the highest amount is observed in the limonite as solid solution within the 
structure/lattice of the iron oxide phases. Analysis number 15 is apatite, 16 is clay and 17 is a gibbsite phase (Table 2).
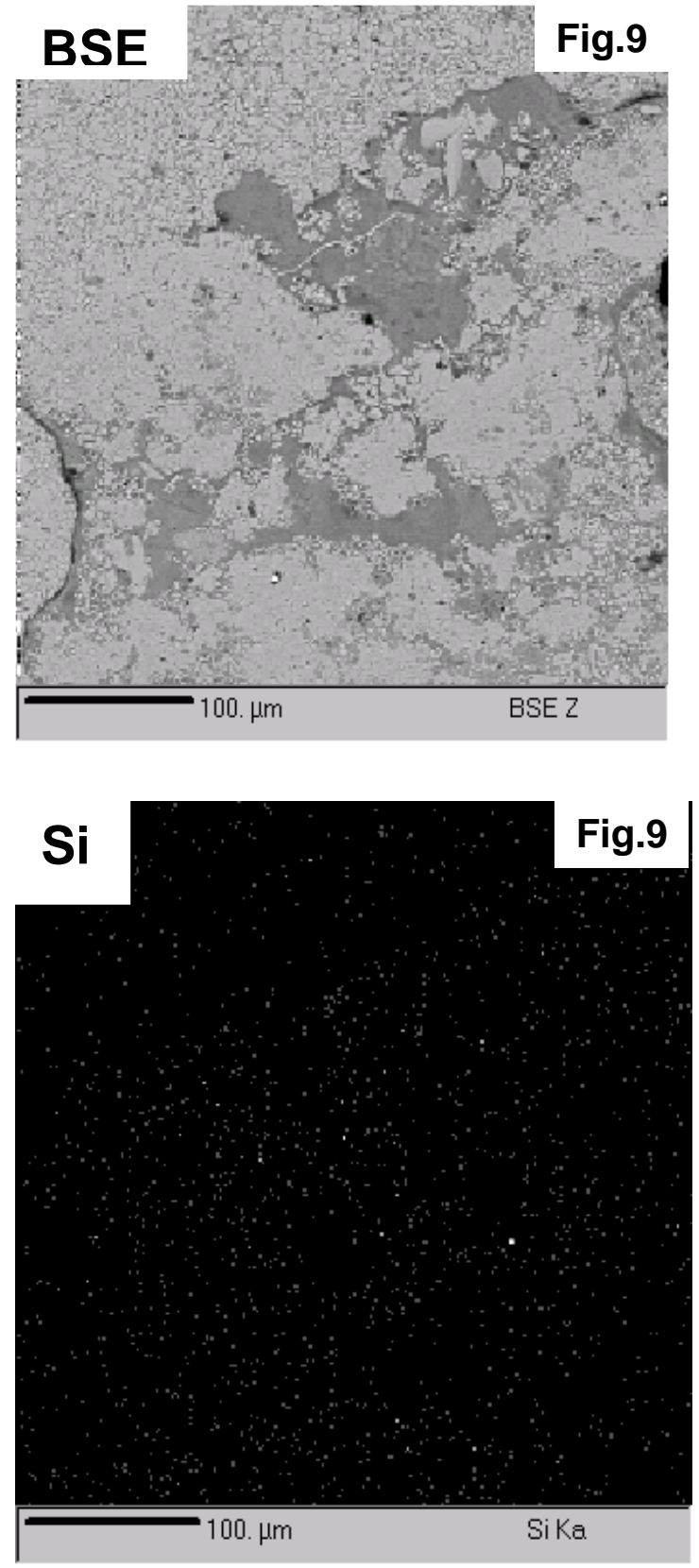
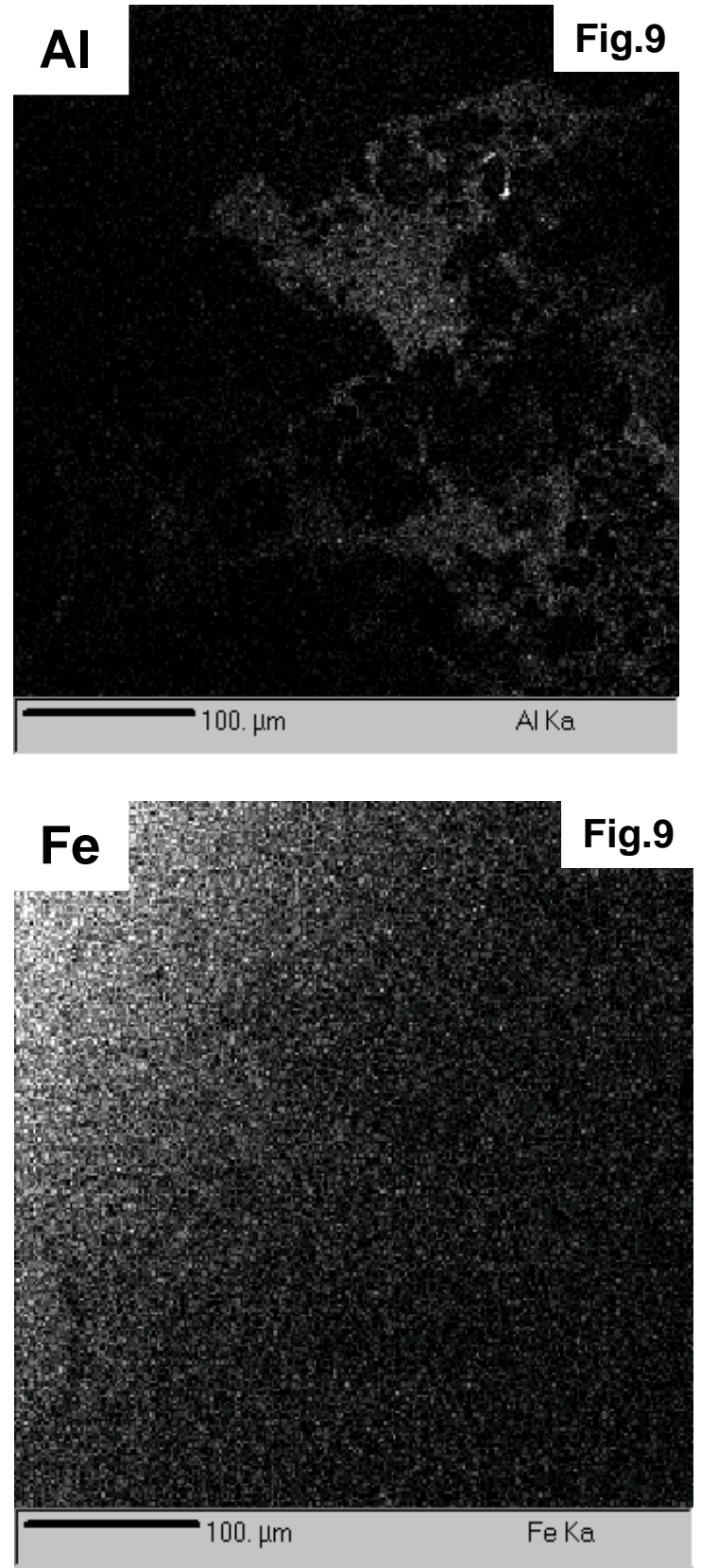

Fig.9: Electron microscopic mapping of an iron ore sample showing presence of gibbsite Mineral along with iron oxide minerals 
Table 2: EPMA analysis of the various iron oxides along with other associated phases

\begin{tabular}{|l|c|l|l|l|l|}
\hline & $\mathrm{Al}_{2} \mathrm{O}_{3}$ & $\mathrm{SiO}_{2}$ & $\mathrm{P}_{2} \mathrm{O}_{5}$ & $\mathrm{Fe}_{2} \mathrm{O}_{3}$ & Total \\
\hline \multicolumn{5}{|c|}{ Hematite } \\
\hline 1 & 0.39 & 0.00 & 0.00 & 94.97 & 95.36 \\
\hline 2 & 0.48 & 1.16 & 0.06 & 95.12 & 96.82 \\
\hline 3 & 1.34 & 0.70 & 0.10 & 91.35 & 93.48 \\
\hline 4 & 1.07 & 1.06 & 0.04 & 92.51 & 94.68 \\
\hline 5 & 0.68 & 0.00 & 0.01 & 95.21 & 95.90 \\
\hline \multicolumn{5}{|c|}{ Goethite } \\
\hline 6 & 4.67 & 0.00 & 0.10 & 76.01 & 80.78 \\
\hline 7 & 3.98 & 0.00 & 0.11 & 76.91 & 81.01 \\
\hline 8 & 2.23 & 0.00 & 0.60 & 85.55 & 88.38 \\
\hline 9 & 2.70 & 1.80 & 0.09 & 82.82 & 87.42 \\
\hline \multicolumn{5}{|l|}{ Limonite } \\
\hline 10 & 2.68 & 1.07 & 0.05 & 60.99 & 64.79 \\
\hline 11 & 7.59 & 0.00 & 0.26 & 70.68 & 78.53 \\
\hline 12 & 6.18 & 0.68 & 0.14 & 71.32 & 78.31 \\
\hline 13 & 1.10 & 0.36 & 0.00 & 68.95 & 70.41 \\
\hline 14 & 8.48 & 0.17 & 0.14 & 57.72 & 66.52 \\
\hline \multicolumn{7}{|l|}{ Other phases } \\
\hline 15 & 0.00 & 1.01 & 44.5 & 0.01 & 45.51 \\
\hline 16 & 18.52 & 69.07 & 0.00 & 0.02 & 87.62 \\
\hline 17 & 59.39 & 1.45 & 0.02 & 0.08 & 60.94 \\
\hline
\end{tabular}

\section{GEOCHEMICAL CHARACTERIZATION}

A of total of forty seven hand picked samples were collected and chemically analyzed. All samples were analyzed for $\mathrm{Fe}_{2} \mathrm{O}_{3}, \mathrm{SiO}_{2}, \mathrm{Al}_{2} \mathrm{O}_{3}$ and $\mathrm{LOI}$ which attests to the above varieties of ores. Diagnostic elemental assemblages of major and minor elemental association can be used to distinguish the varieties of iron ores used in the present case. Hence, a total of 49 samples were drawn (hand picked) and analyzed to decipher the chemical nature of the samples used as the feed material for the test purpose. All these samples were analyzed for $\mathrm{Fe}_{2} \mathrm{O}_{3}, \mathrm{SiO}_{2}, \mathrm{Al}_{2} \mathrm{O}_{3}$ and LOI (Table 3). Salient features of the geochemical studies are as follows

1. From the analysis results it is inferred that these iron ores have wide variation in the $\mathrm{Fe}_{2} \mathrm{O}_{3}$, $\mathrm{SiO}_{2}$ and $\mathrm{Al}_{2} \mathrm{O}_{3}$ content. From the chemical analysis it can be concluded that there are three varieties of iron ore samples viz. iron ore, banded hematite quartzite and wad. That means the physical ore types categorized above are chemically distinguishable in general by its iron, silica 
and alumina content. The hard varieties of iron ores contain higher iron, lower silica as well as alumina while the wad varieties contain lower iron and higher amounts of silica and alumina.

2. It is also inferred that these iron ore samples are totally devoid of sulfide (except pyrite) and carbonate minerals which is indicated by its low LOI value.

3. The percentage of banded hematite quartzite and wad samples in the feed material varies in the range between 5 to $10 \%$.

4. To confirm the above observation on varieties of iron ores, specific gravity studies were conducted (by pycnometer) on all the above 47 hand picked samples. It was observed that specific gravity of the samples decrease with decrease in the $\mathrm{Fe}_{2} \mathrm{O}_{3}$ (Fig.10) content confirming to the geochemical as well as mineralogical studies that other varieties of ore samples like wad and banded hematite quartzite are present. It may be noteworthy that during sampling banded hematite quartzite (BHQ) was observed as micro-bands of silicate in the iron ore samples as shown in the hand specimen photographs.

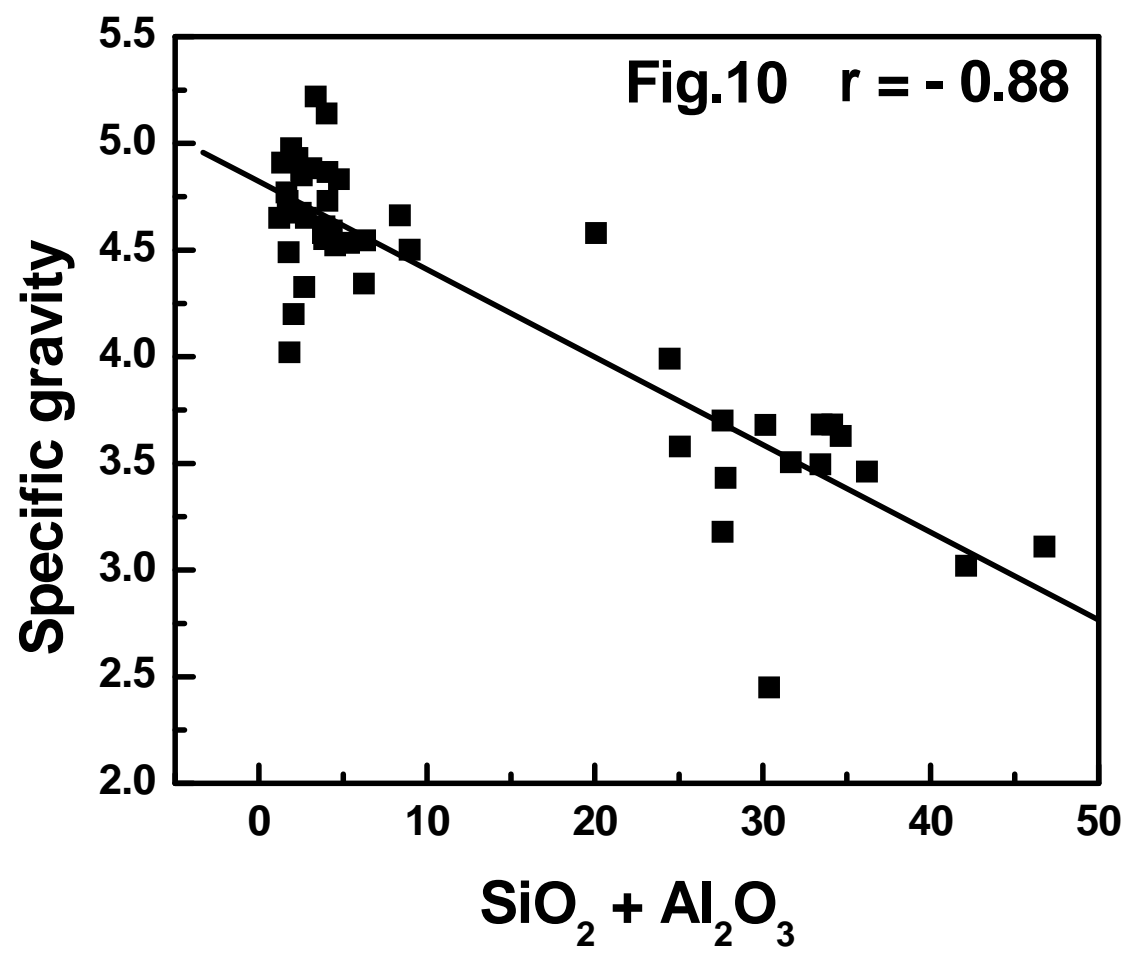

Regression analysis revealed that the iron oxide $\left(\mathrm{Fe}_{2} \mathrm{O}_{3}\right)$ is having a strong negative correlation with silica and alumina (Fig.11 and 12). Silica has a positive correlation with alumina (Figs.13). The negative correlation of iron with silica as well as alumina indicates that iron is present as hematite as well as goethite while silica and alumina are present as completely different phases like quartz and kaolinite. Similar trend is also observed in the case of iron vs. $\left(\mathrm{SiO}_{2}+\mathrm{Al}_{2} \mathrm{O}_{3}\right)$ 
plotting (Fig.14) which clearly suggests that the silica and alumina exists as kaolinite. The weak positive correlation of silica with alumina indicates that they are related in a phase kaolinite over and above silica being present as quartz.
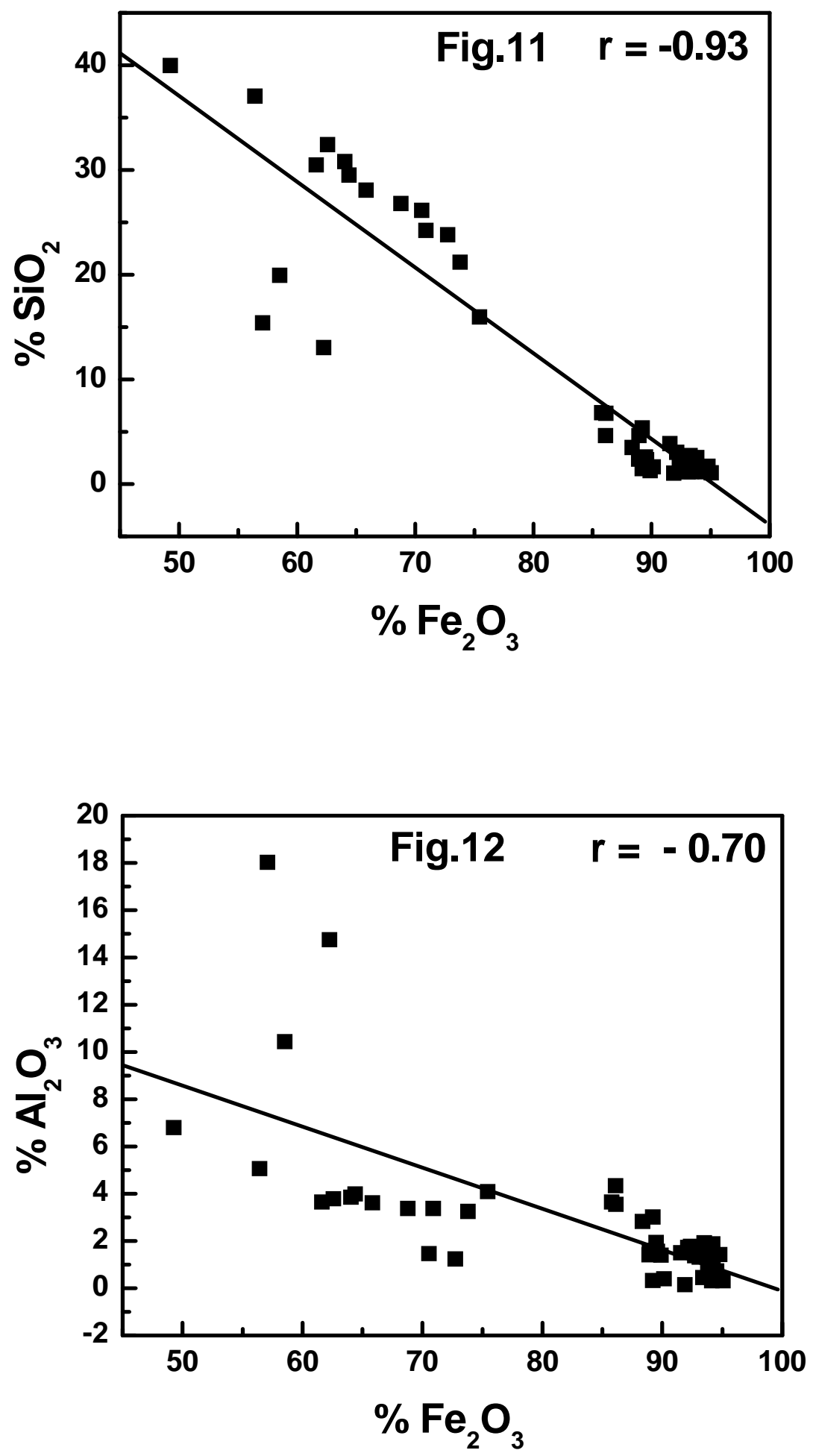

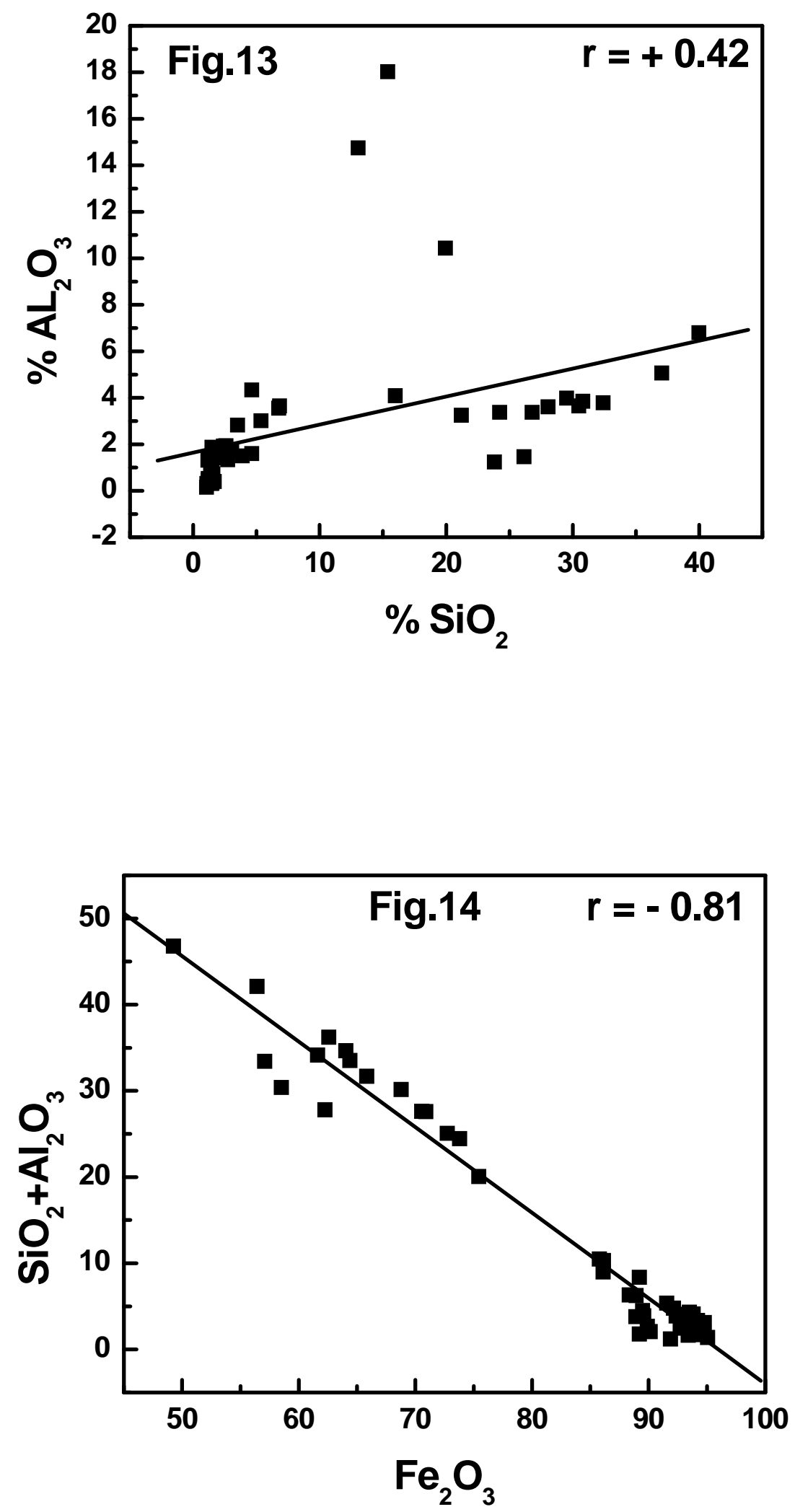
Table 3: Bulk chemical composition of the hand picked samples

\begin{tabular}{|c|c|c|c|c|c|c|c|}
\hline $\begin{array}{c}\text { Sample } \\
\text { ID }\end{array}$ & $\begin{array}{c}\text { \%Total } \\
\text { Fe }\end{array}$ & $\mathrm{Fe}_{2} \mathrm{O}_{3}$ & $\% \mathrm{SiO}_{2}$ & $\% \mathrm{Al}_{2} \mathrm{O}_{3}$ & \%LOI & Total & $\begin{array}{l}\text { Specific } \\
\text { gravity }\end{array}$ \\
\hline 1 & 43.54 & 62.26 & 13.04 & 14.75 & 9.45 & 99.50 & 3.431 \\
\hline 2 & $\begin{array}{l}62.17 \\
\end{array}$ & 88.90 & 2.40 & 1.41 & 6.78 & 99.49 & 4.580 \\
\hline 3 & 40.93 & \begin{tabular}{|l}
58.52 \\
\end{tabular} & 19.94 & 10.44 & 10.59 & 99.49 & 2.450 \\
\hline 4 & 62.65 & 89.58 & 2.33 & 1.56 & 6.02 & 99.49 & 4.611 \\
\hline 5 & 63.03 & 90.13 & 1.66 & 0.40 & 7.36 & 99.55 & 4.199 \\
\hline 6 & 61.79 & 88.35 & 3.50 & 2.83 & 4.81 & 99.49 & 4.545 \\
\hline 7 & 65.87 & 94.19 & 1.48 & 1.88 & 1.94 & 99.49 & 5.220 \\
\hline 8 & 66.08 & \begin{tabular}{|l|l|}
94.49 \\
\end{tabular} & 1.38 & 0.72 & 2.90 & 99.49 & 4.914 \\
\hline 9 & 64.26 & \begin{tabular}{|l}
91.89 \\
\end{tabular} & 1.06 & 0.15 & 6.40 & 99.50 & 4.650 \\
\hline 10 & 65.42 & \begin{tabular}{|l|}
93.55 \\
\end{tabular} & 2.35 & 1.68 & 1.92 & 99.50 & 5.140 \\
\hline 11 & 66.47 & \begin{tabular}{|l|}
95.05 \\
\end{tabular} & 1.08 & 0.31 & 3.06 & 99.50 & 4.910 \\
\hline 12 & 62.38 & \begin{tabular}{|l|}
89.20 \\
\end{tabular} & 1.48 & 0.32 & 8.50 & 99.50 & 4.020 \\
\hline 13 & 65.31 & \begin{tabular}{|l|}
93.39 \\
\end{tabular} & 1.19 & 0.45 & 4.46 & 99.49 & 4.770 \\
\hline 14 & 65.59 & \begin{tabular}{|l}
93.79 \\
\end{tabular} & 1.49 & 1.02 & 3.20 & 99.50 & 4.874 \\
\hline 15 & 66.10 & \begin{tabular}{|l}
94.52 \\
\end{tabular} & 1.19 & 0.53 & 3.25 & 99.49 & 4.731 \\
\hline 16 & 49.34 & \begin{tabular}{|l|}
70.55 \\
\end{tabular} & 26.15 & 1.46 & 1.33 & \begin{tabular}{|l|}
99.49 \\
\end{tabular} & 3.179 \\
\hline 17 & 66.24 & \begin{tabular}{|l}
94.72 \\
\end{tabular} & 1.50 & 0.42 & 2.85 & 99.49 & 4.977 \\
\hline 18 & 65.82 & \begin{tabular}{|l}
94.12 \\
\end{tabular} & 1.45 & 0.31 & 3.62 & 99.50 & 4.490 \\
\hline 19 & 50.88 & 72.75 & 23.82 & 1.24 & 1.68 & 99.49 & 3.579 \\
\hline 20 & 60.21 & \begin{tabular}{|l}
86.10 \\
\end{tabular} & 4.64 & 4.34 & 4.42 & 99.50 & 4.501 \\
\hline 21 & 66.10 & \begin{tabular}{|l}
94.52 \\
\end{tabular} & 1.55 & 0.73 & 2.69 & 99.49 & 4.931 \\
\hline 22 & 39.91 & \begin{tabular}{|l|}
57.07 \\
\end{tabular} & 15.39 & 18.03 & 9.01 & 99.50 & 3.495 \\
\hline 23 & 43.10 & 61.63 & 30.48 & 3.65 & 3.84 & 99.60 & 3.682 \\
\hline 24 & 65.38 & \begin{tabular}{|l}
93.49 \\
\end{tabular} & 2.39 & 1.93 & 1.78 & 99.59 & 4.591 \\
\hline 25 & 44.79 & \begin{tabular}{|l|l}
64.05 \\
\end{tabular} & 30.80 & 3.85 & 0.90 & \begin{tabular}{|l|}
99.60 \\
\end{tabular} & 3.628 \\
\hline 26 & 65.61 & \begin{tabular}{|l}
93.82 \\
\end{tabular} & 2.52 & 1.57 & 1.69 & \begin{tabular}{|l|}
99.60 \\
\end{tabular} & 4.865 \\
\hline 27 & 65.09 & \begin{tabular}{|l|}
93.08 \\
\end{tabular} & 1.17 & 1.31 & 4.04 & 99.60 & 4.675 \\
\hline 28 & 39.46 & \begin{tabular}{|l|}
56.43 \\
\end{tabular} & 37.04 & 5.06 & 1.07 & 99.60 & 3.020 \\
\hline 29 & 43.76 & \begin{tabular}{|l}
62.58 \\
\end{tabular} & 32.41 & 3.79 & 0.83 & \begin{tabular}{|l|}
99.61 \\
\end{tabular} & 3.461 \\
\hline 30 & 34.45 & 49.26 & 39.98 & 6.80 & 2.13 & \begin{tabular}{|l|l}
98.17 \\
\end{tabular} & 3.110 \\
\hline 31 & 51.61 & \begin{tabular}{|l|}
73.80 \\
\end{tabular} & 21.20 & 3.25 & 1.35 & 99.60 & 3.990 \\
\hline 32 & 62.19 & 88.93 & 4.64 & 1.60 & 4.43 & 99.60 & 4.343 \\
\hline 33 & 48.10 & \begin{tabular}{|l|}
68.78 \\
\end{tabular} & 26.79 & 3.37 & 0.66 & \begin{tabular}{|l|}
99.60 \\
\end{tabular} & 3.680 \\
\hline 34 & 64.60 & \begin{tabular}{|l|}
92.38 \\
\end{tabular} & 2.10 & 1.78 & 3.34 & 99.60 & 4.552 \\
\hline 35 & 65.90 & \begin{tabular}{|l|}
94.24 \\
\end{tabular} & 1.19 & 1.35 & 2.82 & 99.60 & 4.850 \\
\hline 36 & 62.86 & \begin{tabular}{|l|}
89.89 \\
\end{tabular} & 1.28 & 1.40 & 7.03 & 99.60 & 4.327 \\
\hline
\end{tabular}


Table 3: Bulk chemical composition of the hand picked samples (continuing)

\begin{tabular}{|l|l|l|l|l|l|l|l|}
\hline $\begin{array}{l}\text { Sample } \\
\text { ID }\end{array}$ & $\begin{array}{c}\text { \%Total } \\
\text { Fe }\end{array}$ & $\mathrm{Fe}_{2} \mathrm{O}_{3}$ & $\% \mathrm{SiO}_{2}$ & $\% \mathrm{Al}_{2} \mathrm{O}_{3}$ & \%LOI & Total & $\begin{array}{l}\text { Specific } \\
\text { gravity }\end{array}$ \\
\hline 37 & 64.83 & 92.71 & 1.40 & 1.38 & 4.12 & 99.61 & 4.650 \\
\hline 38 & 65.22 & 93.26 & 2.73 & 1.34 & 2.27 & 99.60 & 4.730 \\
\hline 39 & 62.58 & 89.49 & 2.58 & 1.94 & 5.59 & 99.60 & 4.522 \\
\hline 40 & 62.38 & 89.20 & 5.37 & 3.01 & 2.01 & 99.59 & 4.663 \\
\hline 41 & 66.28 & 94.78 & 1.70 & 1.43 & 1.69 & 99.60 & 4.884 \\
\hline 42 & 49.58 & 70.90 & 24.23 & 3.37 & 1.15 & 99.65 & 3.700 \\
\hline 43 & 64.02 & 91.55 & 3.87 & 1.50 & 2.68 & 99.60 & 4.534 \\
\hline 44 & 52.76 & 75.45 & 15.98 & 4.09 & 4.08 & 99.60 & 4.580 \\
\hline 45 & 45.10 & 64.49 & 29.52 & 3.99 & 1.60 & 99.60 & 3.682 \\
\hline 46 & 64.43 & 92.13 & 3.04 & 1.73 & 2.70 & 99.60 & 4.832 \\
\hline 47 & 46.03 & 65.82 & 28.06 & 3.61 & 2.10 & 99.59 & 3.505 \\
\hline
\end{tabular}

\section{CONCLUSIONS}

Mineralogical studies by microscope indicated that hematite is the major iron oxide mineral with minor amounts of goethite, magnetite, martite and limonite with quartz and clay (kaolinite) as major gangue. Iron ore deposits of Orissa, India have also similar mineralogical associations (Roy and Das, 2008). There is no evidence of the presence of any iron silicate and iron carbonate minerals. Trace amounts of pyrite were observed under the microscope and is the only iron sulphide phase in these samples. Microscopic studies also indicated that most of the quartz grains are present as inclusions within the hematite and magnetite grains. XRD studies revealed hematite as the major minerals with subordinate amounts of goethite, quartz and kaolinite confirming the microscopic findings. Qualitative mapping and quantitative EPMA studies on these ores indicated the presence of gibbsite as the only alumina bearing phase. Traces of alumina, present as solid solution in the iron oxide minerals, has also contributed to the ores. Electron microscopic studies revealed that gibbsite grains are in the size range of 10 to 50 microns and are intimately and intricately present along with the iron oxide phases.

Geochemistry data revealed negative correlation of $\mathrm{Fe}_{2} \mathrm{O}_{3}$ with silica and alumina thus indicating there is no iron silicate phase as well as alumina contribution from iron oxide minerals in the form of solid solution is insignificant. Positive correlation of silica with alumina indicates that the clay is the major contributing mineral for both the silica and alumina phase and presence of gibbsite. The role of gangue minerals and the interrelationship of silica, alumina and iron oxide, is of paramount importance in the flow sheet development of any ore. Jigs and heavy 
media cyclones for this types of ores can be used but at the cost of poor yield because of complex nature of alumina distribution. As long as alumina and silica mineralization is not too fine and composed of magnetite/hematite with coarse grained quartz magnetic route is most effective. Similar ore types were studied for their beneficiation aspects but even after magnetic separation also the ore could not yield good grade and recovery hence flotation was tried and a better grade as well as recovery was achieved (Vijaya Kumar et al., 2005a, b; Mishra et al., 2007). Since the quartz grains are too fine and their distribution is very complex for the BellaryHospet sector ores, flotation in general and column flotation in particular seems to be more effective. Since in these ores silica is present as quartz and alumina is mostly contributed by kaolinite, which is also a silicate, as these are present as very fine grains, hence chances are there that flotation especially reverse flotation may work better.

Feed characterization is equally important with all other steps in flow sheet development. It can be argued that without proper understanding of the feed it may be impossible, to end with a successful process. Understanding the mineralogical as well as geochemical nature of ore also prevents unnecessary test works and the loss of precious time. A detail characterization of the ore needs the eye of a mineralogist and mind of a mineral processing engineer.

\section{ACKNOWLEDGEMENTS}

The authors are thankful to the Director, National Metallurgical Laboratory, Jamshedpur for his valuable guidance, encouragement and permission to publish this work. The authors are indebted to M/s. JSW, Bellary and Indian Bureau of Mines, Nagpur for chemical and EPMA analysis respectively.

\section{REFERENCES}

1. Vijaya Kumar, T. V., Rao, D. S., Subba Rao, S., More, P., Reddy, Y. S., Prabhakar, S., and Bhaskar Raju, G., (2005a) Beneficiation of iron ore fines by conventional flotation, flotation column and dual extraction column- a pilot scale study. Powder Handling and Process., 17(2), pp.88- 93.

2. Vijaya Kumar, T. V., Rao, D. S., Subba Rao, S., Prabhakar, S., More, P., and Bhaskar Raju, G., (2005b) Semi-commercial scale studies using flotation column and dual extraction column on iron ores of Goa, India. Journal of Minerals \& Materials Characterization \& Engineering., 4(2), pp.113 - 124.

3. Mishra, B.K., Reddy, P.S.R., Das, B., Biswal, S.K., Prakash, S. and Das, S. K. (2007) Issues relating to characterization and beneficiation of low grade Iron ore fines. November issue, Steel World, pp.34-37. 
4. Roy, S. and Das, A. (2008) Characterization and processing of low-grade iron ore slimes from the Jilling area of India. Mineral Processing and Extractive Metallurgy Review, 29(3), pp.213231. 